\title{
Biodiversity of bats in Mysore city
}

\author{
Keshava Murthy $\mathrm{M} \mathrm{V}^{1}$, Pradeep $\mathrm{M}^{2}$, Harshavardhan $\mathrm{J}^{2}$, Ramya $\mathrm{T} \mathrm{M}^{2}$, Sunitha \\ Kumari C K ${ }^{2}$, Tejaswini ${ }^{2}$ and Prakash R Naik ${ }^{2}$ \\ ${ }^{1}$ (Department of Studies in Zoology, Manasagangotri, Mysore. India) \\ ${ }^{2}$ (Department of Studies in Zoology, Manasagangotri, Mysore. India)
}

\begin{abstract}
Present investigation focuses on Biodiversity, roosting and feeding habits of different species of bats in Mysore city. Field visits were carried out during evening hours to observe the roosts. The bats were captured using common commercial mosquito net and are photographed; morphometric data were collected and released immediately. Captured bats were identified by standard keys published earlier. Eleven species belonging to eight genera included in five families are documented during the present study. Roosting sites, food plants were also documented. Results of the present investigation are discussed in comparison with earlier reports.
\end{abstract}

Key words: Bats, Megachiroptera, Microchiroptera Mysore city.

\section{Introduction}

Bats are distributed all over the world and are curious creatures not only because of their number and distribution but also because of their unique ability of flight, which is not seen in any other groups of Mammals [1]. They belong to order Chiroptera and are perhaps the most abundantly distributed, second largest order of class Mammalia, comprising 1232 species belonging to 18 families [2]. Order Chiroptera is divided into suborder Microchiroptera consisting of 1046 species and sub-order Megachiroptera consisting of 186 species. 117 species of bats belonging to thirty nine genera included in eight families are found in India [3]. Thirteen species belonging to four families are documented from Delhi [4].Twenty eight species are recorded from Himachal Pradesh [2]. Fifty two species belonging to twenty five genera and eight families are reported from Western Ghats [5]. In Indian Institute of Science (IISc) campus Bengaluru, seven species belonging to five genera and four families are documented [6].

\subsection{Aims and objecives}

There are no reports on the biodiversity of Bat species of Mysore city; hence the present investigation was initiated as part of M.Sc dissertation work. Objectives of the present investigation are to record the biodiversity in and around the Mysore city and to study the roosting ecology and to further record the feeding habits of the different species of Bats. Twenty $\mathrm{km}^{2}$ area from the center of the city is considered for the present investigation.

\section{Materials And Methods}

The current research work was undertaken from July 2013 to April 2014. Field visits were carried out during evening hours initially to observe the roosts. Researchers and local people were consulted in order to collect the information about roosting sites. Roosts were observed and scanned carefully for the presence of bats. Wherever the bats are roosted, they were carefully captured during their emergence at evening hours. Diurnal captures are strictly avoided which may affect their roosting ecology and they may leave the roost forever. The bats were captured using a common commercial mosquito net. The individuals thus captured were, photographed; morphometric data were collected and released immediately without causing any harm. Global Positioning System (GPS) locations of the roosting and capturing sites are also recorded. Captured bats were identified through morphometric measurements with the help of identification keys of bats, published earlier [7]. After identifying, the names were confirmed by consulting bat taxonomy experts. In order to document the food plants of bats field visits were carried out weekly twice from 18:00 - 21:00 hours. The name of the plant, which the bats visited, parts consumed by them and height of their feeding was also recorded. The plants were identified by their common names in the field and their binomial names and taxonomic positions are clarified with the help of plant taxonomists.

\subsection{Diversity}

\section{Result}

Eleven species of bats belonging to eight genera included in five families are documented during the present study (TABLE 1). While identifying the species the morphometric data such as head to tail length, tail length, forearm length, wingspan, length of tibia, ear length were taken into consideration. Out of the eleven species recorded, seven species fall under the sub order Microchiroptera and four belongs to the sub order: 
Megachiroptera. All the eleven documented species are categorized under Least Concerned (LC) category according to 2001 IUCN red list criteria and categories [8]. Out of the eleven bat species documented, four species belong to the family Vespertilionidae, one species each to family Megadermatidae, Rhinolophidae, Hipposideridae and four belongs to the family Pteropodidae.

Table 1. Table showing species list of bats in Mysore city. (LC-Least Concerned).

\begin{tabular}{|c|c|c|c|c|}
\hline S1 No & Common name & Species & Family & $\begin{array}{l}\text { IUCN } \\
\text { status }\end{array}$ \\
\hline 1 & Common pipisrtellus & Pipistrellus coromandra (Gray, 1838) & Vespertilionidae & $\mathrm{LC}$ \\
\hline 2 & Indian pipistrellus & Pipistrellus tenuis (Temminck, 1840) & Vespertilionidae & $\mathrm{LC}$ \\
\hline 3 & Ceylon pipistrellus & Pipistrellus ceylonicus (Kelaart, 1852) & Vespertilionidae & $\mathrm{LC}$ \\
\hline 4 & Lesser Asiatic yellow house bat & Scotophilus kuhlii Leach, 1821 & Vespertilionidae & $\mathrm{LC}$ \\
\hline 5 & Horse shoe bat & Rhinolophus sp & Rhinolophidae & LC \\
\hline 6 & Schneider's Leaf-nosed Bat & Hipposideros speoris (Schneider, 1800) & Hipposideridae & $\mathrm{LC}$ \\
\hline 7 & Greater false vampire bat & Megaderma lyra E. Geoffroy, 1810 & Megadermatidae & $\mathrm{LC}$ \\
\hline 8 & Indian flying fox & Pteropus giganteus Brunnich, 1782 & Pteropodidae & $\mathrm{LC}$ \\
\hline 9 & Fulvous fruit bat & Rousettus leschenaultii (Desmarest, 1820) & Pteropodidae & $\mathrm{LC}$ \\
\hline 10 & Greater short nosed fruit bat & Cynopterus sphinx (Vahl, 1797) & Pteropodidae & LC \\
\hline 11 & Lesser short nosed fruit bat & Cynopterus brachyotis (Muller, 1838) & Pteropodidae & $\mathrm{LC}$ \\
\hline
\end{tabular}

\subsection{Roosting ecology}

Roosting sites of nine species out of the eleven studied species are recorded during the present study (TABLE 2). One roost of $H$ speoris, Rhinolophus sp are found in the drainage behind department of Zoology, Manasagangotri, Mysore. One of the curious observations here is that both H speoris and Rhinolophus are found in the same roost. P tenuis, roost was observed in crevices of old dilapidated buildings, (TABLE 2). $S$ kuhlii found roosted in a Jubea chilensis tree in a granite factory near Bamboo Bazaar. M lyra roost is found in a ruined water tank in Chamundi hill reserve forest, Mysore. Four roosts of P.giganteus are documented; it preferred roosting in the upper canopy level. Almost all the individuals occupy a safest height of about 100 to 150 feet. One roost is in Sri Chamarajendra Zoological garden, Mysore, one beside the Kukkarahalli lake in Mysore University campus, another on the bank of Subbarayana kere, Srirampura and other roost is in Defence Food Research Laboratory (DFRL) Mysore. Roosting is observed in several tree species such as Eucalyptus, Tamarindus indica, Bambusa arundinacea, Grevillea robusta (TABLE 2). R lescheonaultii roost is documented from a disused paper mill's roof near Kesere in of Mysore city. A roost of $C$ sphinx is found in Yuvaraja's college campus. Here $C$ sphinx roost is seen in an old ruined building. Roost of $C$ brachyotis is observed in the Borassus flabellifer plant where the individuals cling themselves below the huge leaves.

Table 2. Table showing roosting sites of bats of Mysore city.

\begin{tabular}{|c|c|c|c|c|}
\hline & Species & Habitat of the roost & Bat roost/tree & Roost size \\
\hline 1 & H speoris & $\begin{array}{l}\text { Drainage department of Zoology, } \\
\text { Manasaganotri, Mysore. } \\
\text { Lalith mahal palace road, Chamundi }\end{array}$ & Roof of the tunnel & $100-150$ \\
\hline 2 & Rhinolophus sp & $\begin{array}{l}\text { Hill, Mysore. } \\
\text { Drainage department of Zoology, } \\
\text { Manasaganotri, Mysore. }\end{array}$ & $\begin{array}{l}\text { Roof of the tunnel } \\
\text { Roof of the tunnel }\end{array}$ & $\begin{array}{l}100-200 \\
\text { About } 40\end{array}$ \\
\hline 3 & S kuhli & $\begin{array}{l}\text { Bannimantap road, Granite factory, } \\
\text { Kesare, Mysore. }\end{array}$ & Jubea chilensis tree & About $75-100$ \\
\hline 4 & Ptenuis & Near bamboo bazaar, Mysore. & Crevices of a building & 8-10 \\
\hline 5 & M lyra & Chamundi hill reserve forests, Mysore. & Roof of ruined water tank & 15 \\
\hline 6 & R lescheonaultii & K R mill, Kesare, Mysore & Roof of the disused building & 2500-3000 \\
\hline 7 & C sphinx & Yuvaraja's college campus, Mysore & Ruined building & 2 \\
\hline 8 & C brachyotis & Srirampura, Mysore & Borassus flbellifer tree & $50-100$ \\
\hline \multirow[t]{3}{*}{9} & P gigantes & $\begin{array}{l}\text { Beside University of Mysore and } \\
\text { Paduvarahalli road }\end{array}$ & $\begin{array}{l}\text { Delonix regia } \\
\text { Eukalyptus sp } \\
\text { Tamarindus indica } \\
\text { Bambusa arundinacea } \\
\text { Grevillea robusta }\end{array}$ & $1000-1500$ \\
\hline & & $\begin{array}{l}\text { Sri Chamarajendra Zoological Garden, } \\
\text { Mysore. }\end{array}$ & $\begin{array}{l}\text { Delonix regia } \\
\text { Tamarindus indica }\end{array}$ & $1000-1100$ \\
\hline & & Subbarayana Kere, Srirampura, Mysore. & Ficus bengalensis & $800-1000$ \\
\hline
\end{tabular}




\subsection{Feeding ecology}

A total of 16 species of plants to which bats visit and feed upon its fruits are documented during the current survey (TABLE 3). These plants provide fruits, leaves, flowers, nectar, and pollen for four documented pteropodid bats. Flight preference of these bats differs though they feed on almost similar type of plants. $P$ gignteus always stays above 17-20 feet above the ground, however $C$ sphinx, $\mathrm{C}$ brachiotis, $R$ lescheonaultii feed below this height. According to the earlier published data [9], C sphinx feeds upon leaves of Tamarindus indica plant but we have not observed any such behavior during our study. Out of 16 species of food plants of bats documented $P$ giganteus was found to feed on only eight species of fruits. Six species of plants were documented while $R$ lescheonaultii was feeding. Fourteen species of plants were documented that provide food for $C$ sphinx and $C$ brachyotis. These varieties of fruit plants provide food for fruit bat population throughout the year. During the study, fruiting of $M$ calabura (Singpore cherry, one of the introduced species) and $P$ guajava was observed throughout the year.

Table 3: Table showing different fruits consumed by four documented fruit bats of Mysore city. $[(+)=$ plants consumed, $(-)$ = Plants not consumed].

\begin{tabular}{|c|c|c|c|c|}
\hline Plant & $P$ giganteus & R lescheonaultii & $C \operatorname{sphin} x$ & C brachyotis \\
\hline Polyalthia longifolia & - & - & + & + \\
\hline Annona squamosa & - & - & + & + \\
\hline Annona reticulata & - & - & + & + \\
\hline Carica papaya & + & + & + & + \\
\hline Ficus religiosa & + & - & - & - \\
\hline Ficus bengalensis & + & - & - & - \\
\hline Ficus recemosa & + & + & + & + \\
\hline Psidium guajava & + & + & + & + \\
\hline Syzigium cumini & - & - & + & + \\
\hline Samania saman & + & + & + & + \\
\hline Musa paradisiaca & - & - & + & + \\
\hline Muntingia calabura & - & - & + & + \\
\hline Limonia acidissema & + & + & + & + \\
\hline Manilkara zapota & + & + & + & + \\
\hline Punica granatum & - & - & + & + \\
\hline Delonix regia & - & - & + & + \\
\hline
\end{tabular}

\section{Discussion}

Bat species richness of the Mysore city is comparatively lower than that of Himachal Pradesh. 28 species of bats within 14 genera 5 families are reported from Himachal Pradesh [2], but only eleven species belonging to eight genera and six families are documented in Mysore city. P gianteus, R leschinaulti, $S$ kuhli, $P$ coromandra, $P$ ceyloniucs, $P$ tenuis and $M$ lyra are recorded in both the regions. Three species namely $C$ sphinx, $C$ brachyotis and $H$ speoris which are very common in Mysore city are not reported from Himachal Pradesh. The species richness of Mysore is comparatively higher than that of, IISc campus, Bengaluru, and Coorg district. In Delhi In Indian Institute of Science (IISc) campus Bengaluru, seven species belonging to five genera and four families are documented [6]. Nine species belonging to seven genera and five families are reported from Coorg [10].

Four roosts of Pteropus giganteus are documented from Bangalore urban and four from Mysore city. Tall trees of around 100 feet or more height are preferred for roosting. Trees such as Eukalyptus, Tamarindus indicus, Delonyx regia, Samania saman are the main roosting sites for $P$ giganteus. Roosts of other bats are also documented from both the regions. Out of these the Pipestrellus sp were found in crevices, cracks of window, rock etc. C sphinx roost was documented in a window eave in IISc campus [6] while in Mysore it is recorded in a roof of old disused building. However no roosts of other species recorded so far, are not reported from Bangalore urban.

\section{Acknowledgements}

Authors are thankful to Chairman Department of Studies in Zoology, Manasagangotri, Mysore for extending all the help required for the present study. Indeed authors are grateful to Sapta Girish and Rathina Kumara, who helped us in identifying the bat species. 


\section{References}

[1] Kunz, T.H., Torrez, E.B., Bauer, D., Lobova, T., and Fleming, T.H., Ecosystem services provided by bats. Annals of the New York Academy of Sciences. New York. 1-38 (2011)

[2] Saikia, U., Thakur, M.L., Bawri, M and Bhattacherjee, P.C., An inventory of the chiropteran fauna of Himachal Pradesh northwestern India with some ecological observations. Journal of Threatened Taxa. 3(4), 2011, 1637-1655

[3] Srinivasalu, C., Racey, A.P and Mistry, S,. A key to bats (Mammalia: Chiroptera) of South Asia. Journal of Threatened Taxa. 2, 2010, 1001-1076

[4] Srinivasalu, C., Srinivasalu, B., Bats of Delhi: an Update. BAT NET-CCINSA Newsletter.8, 2007, 30-31

[5] Korad, V., Yardi, K., and Raut, R.,Diversity and distribution of bats in the western ghats of India. Zoo's Print Journal 22(7), 2007, 2752-2758

[6] Pramod, P and Krishan, R., Bats of Indian Intitute of Science campus. Current Science. 76(6), 1999, 716

[7] Bates, P. and Harrison, D., Bats of the Indian Subcontinent (Harrison Zoological Museum, Harrison, UK, 123 -258. 1997)

[8] Molur, S., Marimuttu, G., Srinivasalu, S., Mistry, A.M., Hutson. Bates, P.J.J., Walker, K., Priya, P and Priya, B., Status of South Asian Chiroptera: Conservation Assessment and management plan (C.A.M.P) Workshop report, Zoo Outrich organization, Coimbatore, 2002, 141-144

[9] Sudhakaran, M.R., and Doss. P.S.,Food and foraging preferences of three pteropodid bats in southern India. Journal of Threatened Taxa. 4, 2012, 2295- 2303

[10] Molur, S., Habitat and status assessment of Mammals with special reference to Rodents and Bats in Southern Karnataka, PhD thesis, University of Mysore, 2009, 115-125 